\title{
Economic Feasibility of an Alternative Fuel for Sustainable Short Sea Shipping: Case of Cross-Taiwan Strait Transport
}

\author{
Yi-Hsuan Wu ${ }^{1}$, Jian Hua ${ }^{2}$, Hsin-Ling Chen ${ }^{1}$ \\ ${ }^{1}$ Soochow University \\ 56 Gueiyang Street Section 1, Taipei, Taiwan ROC \\ wuyihsuan@scu.edu.tw \\ ${ }^{2}$ National Taiwan Ocean University \\ 2 Beining Road, Keelung, Taiwan ROC \\ huajian@ntou.edu.tw
}

\begin{abstract}
Marine shipping has experienced increasing pressure in recent years to reduce its emissions of the greenhouse gases and many key air pollutants. The use of liquefied natural gas (LNG) as ship fuel has been proposed as one of the effective solutions for the problem, mainly because it makes possible simultaneous reduction of both greenhouse gases and key air pollutants. In this study, we want to find out whether the technology can still be as beneficial a solution for ships operating in Taiwan Strait, where no ECA is currently designated while the LNG prices are typically much higher.

We analyzed the economic feasibility of retrofitting existing vessels to run on LNG, using two typical types of vessels operating across the Strait as examples, one feeder and one ferry. We considered two different scenarios of HFO price forecast and three scenarios of LNG price forecast, and evaluated the fuel switch based on net present value, annualized net benefit, and the discounted payback period. Consistent with previous studies, our result found that the economic feasibility depends on the price differentials of HFO and LNG. Furthermore, we found the feasibility varied across types or operation methods of vessels. It is generally more feasible for the feeder than for the ferry. The technology investment has positive net present value under most scenarios for the feeder, but only half of the scenarios for the ferry. The investment requires payback period of more than 10 years under all but two cases, with the shortest one being 6.78 years. Marginal abatement cost ranges from -0.126 to 0.040 USD per $\mathrm{kg}-\mathrm{CO}_{2} \mathrm{e}$ when considering GHG reduction alone, indicating minimal economic benefit realizable from the application. As a result, we suspected the strategy would attract as much interest from the marine shipping companies operating around Taiwan Strait.
\end{abstract}

Keywords: Economic Feasibility, LNG, Marine Fuel, Sustainable, Short Sea Shipping, Taiwan Strait.

\section{Introduction}

Marine shipping plays an important role in the growth of international trade and economic development around the world, and is the most energy-efficient transport mode in terms of tone-miles. Marine shipping has nevertheless experienced increasing pressure in recent years to reduce its emissions of the greenhouse gases and many key air pollutants. The International Maritime Organization (IMO) adopted in 1997 Annex VI of the International Convention for the Prevention of Pollution from Ships (MARPOL 73/78) to address the issue of air pollution from ships, specifically SOx and NOx, which has taken effect since 2015 [1]. In addition, given that coastal and harbors with high volume of shipping activities and dense population are more vulnerable to the issues caused by ship emissions, higher emission standards were required in the designated environmentally sensitive areas, the so-called $\mathrm{SO}_{\mathrm{x}}$ Emission Control Area (SECA) or Emission Control Areas (ECAs) [1], [2].

Emission problems of marine shipping mainly come from its choice of heavy fuel oil (HFO) as energy source. The combustion exhaust contains pollutants such as particulate matter, especially with diameter smaller than 2.5 micrometers (PM2.5), nitrogen oxides (NOx), sulfur oxides (SOx), which are detrimental to human health and ecosystem. It is of priority concern because approximately $70 \%$ of ship-originated emissions occur within $400 \mathrm{~km}$ of coastlines, globally [3], [4], causing environmental issues in coastal and harbors regions with busy traffic [5], [6], [7]. Another concern for atmospheric emissions from ships is they contribute to greenhouses gases (GHGs), worsening anthropogenic climate change [8], [9]. 


\subsection{Environmental Benefits of Fueling with LNG}

Natural gas promises a better environmental performance compared to traditional marine fuel oil. Natural gas mainly consists of methane and using as marine fuel significantly reduces emissions of SOx, as well as $\mathrm{NOx}$ and $\mathrm{CO}_{2}$, as reported from previous researches [10], [11], [12], [13] and [14]. Studies suggested, however, that there is a need for the natural gas industry and science community for increased efforts to reduce methane leakage in order to minimize the climate footprint of natural gas [12], [14].

Natural gas is usually liquefied when used as marine fuel due to limited storage space on board ships. From a fuel lifecycle perspective, liquefied natural gas (LNG) caused much fewer local air pollutants, such as sulfur oxides and particulate matter, than traditional petroleum-based fuels in the marine sector [14], [15]. The implications for greenhouse gases, however, depend on how the natural gas is extracted, processed, distributed, and used [15], [16]. Liquefaction of natural gas requires additional energy and therefore may cause increase in GHG emissions.

\subsection{Economic Considerations}

LNG is a promising alternative fuel for marine shipping since it offers potential cost savings in addition to ensuring compliance with ECA regulation [17], [18]. But investment to retrofit existing vessels to be able to use LNG may incur significant upfront costs, and a high degree of uncertainty remains on the differential between the prices of LNG and conventional maritime fuels, as well as on the availability of LNG and the reliability of its supply chain.

The LNG-powered ships in operation are usually equipped with lean-burn (high air-fuel ratio) gas engines or dual-fuel engines [11]. In addition, the conversion to combust LNG requires major retrofits involving LNG storage tanks, gasifying system, fuel supply systems, piping systems, and inert gas systems for safety purpose [10], [19]. On the other hand, however, changing fuel from marine fuel oil to LNG implies the lower maintenance and operating cost afforded by cleaner and more efficient systems and a longer lifetime of whole system [20]. On the other hand, it is widely recognized that the LNG price and availability plays an important role in the economic consideration on the use of natural gas as a ship fuel [16], [21], [22], [14]. Sames et al. [21] concluded that recent low LNG prices in Europe and the USA suggested that a price below heavy fuel oil (HFO) seemed possible, even when taking into account the small-scale distribution of LNG.

However, economic considerations may vary regionally, and may be specific for short sea shipping. Thomsom et al. [14] found that relative price advantage of LNG over HFO varies regionally, so as and the expected demand for new technology of LNG application on board ship. The study also suggested a transition to natural gas is likely to be justified on both economic and air quality dimensions for short sea shipping. Verbeek et al. [16], however, concluded that the physical installation of the LNG fuel tank on board can be an issue for smaller ships, such as small containerships, tugs or service vessels - especially critical for the application on the tug.

\subsection{Purpose of the Study}

Switching to use LNG as ship fuel, therefore, has been proposed as one of the effective solutions for the problem, mainly because it makes possible the simultaneous reduction in the emissions of both greenhouse gases and major air pollutants. The approach has gained even more attention in Europe and USA because of current relatively lower LNG prices. It is therefore worth exploring whether such new technology, being attractive to marine shipping business operating in European or US waterways, can also be a beneficial solution for those operating in Asian waters, and particularly in Taiwan Strait, where the emission standard is lower while the LNG prices are typically much higher.

This study, therefore, targeting cross Taiwan Strait transportation, explores whether a switch to the use of LNG as ship fuel can be a beneficial strategy for ship owners in reduction of atmospheric emissions. We carried out the study on two typical types of vessel operating across the Strait, one feeder and one ferry. We conducted an economic analysis of the fuel switches, considering two different scenarios of HFO price forecast and three scenarios of LNG price forecast. In addition, we assessed the cost effectiveness of such an abatement strategy in reducing the emissions of GHG and air pollutants.

\section{Methods}

\subsection{Ship Cases}

We used a container ship (Feeder A) and a passenger-cargo ship (Ferry B) as target case ships in this study, considering their foreseeable popularity for operation across the Strait. We assumed both vessels operate on a prearranged schedule throughout the year. Feeder A operated in a looped trip from Keelung, stop at Taipei, Taichung, Ningbo, then to Shanghai, and then back to Keelung, while Ferry B alternated between two lopped trips: one from Xiamen to Keelung, and the other 
from Xiamen to Kaohsiung, Taichung, then back to Xiamen. Table 1 provides the details of the two case ships assumed for the energy study. The emissions of the auxiliary engine for generating electricity are assumed to make up 5\% of the main engine. The mechanical energy used to propel the ship is dependent on the standard load pattern of main engine.

Table 1: Ship cases defined for energy study.

\begin{tabular}{|c|c|c|}
\hline & Feeder A & Ferry B \\
\hline Application & $\begin{array}{l}\text { Container shipping between port of } \\
\text { Shanghai, China, and Keelung, Taiwan }\end{array}$ & $\begin{array}{l}\text { Passenger and cargo shipping between } \\
\text { Xiamen, China and Keelung, Taiwan }\end{array}$ \\
\hline $\begin{array}{l}\text { Specification of } \\
\text { ship }\end{array}$ & $\begin{array}{l}\text { - } 1,805 \text { TEU containers } \\
\text { - } 16,776 \text { gross tonnage } \\
\text { - } 172-\mathrm{m} \text { long } 28-\mathrm{m} \text { wide } \\
\text { - } \text { Design speed } 21 \mathrm{knots} \\
\text { - } \text { Output } 15,820 \mathrm{~kW} \\
\text { Average speed } 20 \mathrm{knot}\end{array}$ & $\begin{array}{l}\text { - } \text { 683-passenger, } 256 \text { TEU containers } \\
\text { - } 26,847 \text { gross tonnage } \\
\text { - } 112 \text {-m long } 21 \text {-m wide } \\
\text { - Design speed } 35 \mathrm{knots} \\
\text { - } \text { Output } 12,577 \mathrm{~kW} \\
\text { Average speed } 22.9 \mathrm{knot}\end{array}$ \\
\hline
\end{tabular}

Table 2 summarizes energy consumption during ship operation. Considering the lack of completed data, we calculated the energy use at the key points using linear curve fits where energy use is shown as a function of operating engine load.

Table 2: Distances and duration of navigation per voyage.

\begin{tabular}{|l|c|c|}
\hline & Feeder A & Ferry B \\
\hline Average speed (nautical mile/hour) & 20.00 & 22.85 \\
\hline Distance (nautical mile) per voyage & 1,044 & 1,013 \\
\hline Duration (hour) per voyage & 52.20 & 44.33 \\
\hline Energy required, run on HFO (Mm BTU) & 6,125 & 4,135 \\
\hline Energy required, run on LNG (Mm BTU) & 6,404 & 4,324 \\
\hline
\end{tabular}

\subsection{Relevant Expenditures and Cash Flows}

\subsubsection{Capital Expenditure}

It is expected that a substantial amount of capital expenditure is required when retrofitting a traditional HFO-fueled merchant ship to become fueled by LNG. The expenditure is to cover additional equipment on board ship such as LNG storage tanks, fueling equipment, piping system, as well as the LNG-powered engine itself. Installation and testing are typical add-on cost as well. These costs may vary with the power requirement of the ship retrofitted [21].

We adopted the method used in a recent study performed by MAN Diesel \& Turbo, one of the two world-largest manufacturers of marine engine and power system, to derive estimates of capital expenditure [21]. The capital expenditure was assumed to vary with the maximum power rating of two case vessels.

\subsubsection{Fuel Costs}

We estimated the annual fuel costs based on the yearly fuel requirement of the two case ships' current operation. In the estimation, we assume both ships remain in operation repeating current regular schedule for the whole year, except for the no service period due to weather, season, or scheduled maintenance.

Given that this study was to compare the possible fuel cost difference between fueling by HFO and by LNG, we need to establish estimates for the prices of both fuels 20 years into the future. In the scenarios for HFO, we assumed ships would bunker at ports in China. As a result, we forecasted HFO prices at either Shanghai or Xiamen.

We estimated HFO prices to be $91 \%$ of crude oil prices, given that a close linkage existed between prices for the two products, and prices of HFO tended to maintain a discount from that of crude oil [21]. We established two different scenarios of HFO price movement to account for the uncertain nature of the future price movement, based on a different source of crude oil price forecast: (1) a 2013 forecast from the two class organizations, Det Norske Veritas and German Lloyds (DNVGL) [23], and (2) a 2013 forecast from Organization of Petroleum Exporting Countries (OPEC) [24]. DNV's forecast 
is based on the 2012 World Energy Outlook released by International Energy Agency. Both sources supplied crude oil price forecasts for certain years only, for example, only 2020, 2025, 2030, and 2035. We then use interpolation method to estimate inter-year crude prices wherever the sources have not provided a forecast.

For LNG, we followed [21] and estimated imported LNG price by adding US\$4 per mmBTU distribution costs to the wholesale LNG price. Again, we adopt three different scenarios of future LNG prices out of concern of price uncertainty, each based on a different source of wholesale LNG forecast: a 2013 forecast from DNVGL [23], and two versions of LNG price forecast provided by ACIL Allen Consulting (ACIL) in 2012 [25]. Reports have shown that LNG prices in China are lower than in Japan, Korea and Taiwan by approximately US $\$ 3$ to 4 per mmBTU [26]. We adjust DNV's forecast prices for LNG downward by US\$4 per mmBTU to account for the LNG price difference between Japan and China, given that DNV's LNG price forecasts are for import to Japan.

Based on the two scenarios of HFO price forecast and three scenarios of LNG price forecast, we established six relative price scenarios based on the six possible combinations of future fuel price forecast.

\subsubsection{After-tax Net Cash Inflows}

During the period after the LNG system is installed, the relevant cash flows resulted from the installation include the differential costs (or savings) from annual fuel costs, and the tax savings from depreciation deduction. Since we assume the difference is minimal in operation and maintenance costs between a HFO system and a LNG system, we do not consider the differential cash flow from such component. In this study, we adopted the 2012 effective income tax rate of a representative Taiwanese container shipping company for our analysis.

\subsection{Economic Evaluation}

We used three different methods to evaluate the economic feasibility of converting a merchant ship to run on a LNG system, including (1) net present value method, (2) annualized net present value method, and (3) discounted payback period. We used weighted-average cost of capital (WACC) to estimate the discount rate needed for the three economic evaluation methods. WACC considers a company's after-tax cost of raising all sources of capital, including debt and equity, and calculates an average cost of capital in which each category of capital is proportionately weighted. Given that cost of equity is generally unobservable, we adopted Capital Asset Pricing Model (CAPM), the most commonly used method, to estimate the cost of equity capital. WACC was estimated using 2012 data of a specific marine shipping company, which are obtained from Taiwan Economic Journal (TEJ) database, including cost of debt financing, market value of equity capital, market value of long-term debt financing, marginal rate of corporate income taxes, beta coefficient, and expected return of market. The risk-free rate of interest was determined by weighted-averaging accepted yields of 20 -year central government bonds issued in 2012.

\subsection{Cost Effectiveness}

We used the marginal abatement costs (MAC) for reducing one unit of emissions to assess the cost effectiveness of the emission abatement resulted from changing fuels, as described in Equation (1):

$$
M A C_{i}=\frac{A N P V}{E M_{i, H F O}-E M_{i, L N G}}
$$

where,

$M A C_{i} \quad$ is the marginal abatement costs $(M A C)$ for reducing one unit of airborne emission $i$, where $i$ represents either $\mathrm{GHG}, \mathrm{SO}_{2}, \mathrm{NO}_{x}, \mathrm{CO}$ or PM

$A N P V \quad$ is the annualized net present value of the all expected cash inflows and outflows arisen from changing fuel to LNG, including initial capital expenditures, fuel cost differentials, and taxes.

$E M_{i, H F O}$ is the annual airborne emission $i$, where $i$ represents either $\mathrm{GHG}, \mathrm{SO}_{2}, \mathrm{NO}_{\mathrm{x}}, \mathrm{CO}$ or $\mathrm{PM}$, caused by operating the ship using HFO as fuel.

$E M_{i, L N G} \quad$ is the annual airborne emission $i$, where $i$ represents either $\mathrm{GHG}, \mathrm{SO}_{2}, \mathrm{NO}_{\mathrm{x}}, \mathrm{CO}$ or $\mathrm{PM}$, caused by operating the ship using LNG as fuel. 
Marginal abatement costs were computed for GHG, SO2, NOx, CO or PM separately, without considering the emissions of other particles. As a result, this method estimates the maximum MAC for the reduction of one specific kind of emissions alone. The real MAC is expected to be lower given that the various kinds of emissions are reduced at the same time.

In this study, we considered the full fuel life-cycle atmospheric emissions of operating the ships using HFO and LNG as fuels for the case ships. This method included all emissions from the use of fuels across four fuel life-cycle stages, i.e. exploration and extraction, production, transportation, and consumption. We counted the emissions for full fuel life cycle, instead of emissions from operation stage only, to reflect the potential reduction in upstream emissions that may have achieved due to the fuel choice decision.

Given that Saudi Arabia is the largest source of crude oil to both China and Taiwan, we assumed crude oil are imported from Yanbu, Saudi Arabia, and then refined locally to produce heavy fuel oil. In the scenarios for HFO, we assumed ships would bunker at ports in China, at Shanghai for Feeder A and at Xiamen for Ferry B. In the scenarios for LNG, we assumed ships could only bunker at ports in China, taking into account the recent development in domestic production of natural gas in China. Taiwan, on the other hand, has to rely on LNG import to fulfil industrial demand for natural gas. We thus assume bunkering LNG at Taiwan's ports is not likely in the near future due to inadequate supply and possibly higher prices. Dampier, Australia, is the source for imported LNG for both Feeder A and Ferry B. LNG is bunkered at Shanghai for Feeder A, and at Xiamen for Ferry B.

The inventory for a full fuel life cycle includes all energy flows and emissions associated with the fuels' production and use - starting with the raw material (crude oil or natural gas) procurement and ending with fuel consumption. Thus, the annual emissions $E M_{j, H F O}$ or $E M_{j, L N G}$ was calculated by summing up all emissions from ship operation and all upstream stages. Emissions from a particular upstream process are calculated by using Equation (2):

$$
E M_{i, k}=\left(\sum_{k} E F_{i, k}+\sum_{j} E F_{i, j, k} \times X_{j, k}\right) \times Y_{k}
$$

Where,

$E M_{i, k} \quad$ represents emissions of pollutant $\mathrm{i}$ in $\mathrm{kg} /$ year from upstream process $\mathrm{k}$

$E F_{i, k} \quad$ represents the emission factor of pollutant i for one unit of output from the upstream process $\mathrm{k}$

$E F_{i, j, k} \quad$ represents the emission factor of pollutant $\mathrm{i}$ for one unit of input $\mathrm{j}$ used to produce output of process $\mathrm{k}$

$X_{j, k} \quad$ represents the amount of input $\mathrm{j}$ required to produce one unit of output of process $\mathrm{k}$

$Y_{k} \quad$ represents the amount of output from process $\mathrm{k}$, and is also the amount of input required for next downstream process.

Calculation method of the total fuel life-cycle emissions was documented in more detail in [15].

\section{Results and Discussion}

\subsection{Economic Evaluation}

Our estimates of the initial capital expenditure for Feeder A and Ferry B is US\$6,486,200 and US\$5,156,570, respectively. We assumed 20 years of economic life for the engine retrofit and zero salvage value at the end of the useful life. Using the straight-line method, we computed the yearly depreciation of Feeder A as US\$324,310, while Ferry B as US $\$ 257,828.5$.

As explained earlier in Section 2, we constructed two scenarios of HFO prices based on different sources of crude oil price forecast and three different scenarios of future LNG prices, each of which based on a different source of wholesale LNG forecast. As a result, we established for each of the ship six possible net cash flow estimates based on the six possible combinations of future fuel price forecast.

Table 3 presents the economic evaluation result for Feeder A under the six relative fuel price scenarios. In five out of the six scenarios, converting feeder A to run on LNG would generate positive NPV and ANPV, and the project will payback within the economic life of the new system. The investment would achieve payback the fastest if the relative-price scenario were as under scenario 3. This is due to the fact that HFO prices per mmBtu are typically US\$5 to 6 higher than LNG prices. Discounted payback period under such scenario is only 6.78 years, and NPV is US\$7,740,515.73, which is equivalent to annual after-tax net benefits of US\$499,864.53. On the other hand, the price difference between two fuels is only US\$1 to 2 per mmBtu under Scenario 1. The savings resulted from lower fuel costs plus the tax savings from depreciation are too small 
to reach a fast recovery of the original capital expenditure. This resulted in a relatively small amount of NPV and ANPV, and a very long discounted payback period (nearly 20 years).

Table 3: Economic Evaluation of Retrofitting Feeder A.

\begin{tabular}{|c|c|c|c|}
\hline $\begin{array}{c}\text { Relative Fuel-Price } \\
\text { Scenarios }^{2}\end{array}$ & $\begin{array}{c}\text { Net Present Value } \\
\text { (NPV) } \\
\text { (US\$) }\end{array}$ & $\begin{array}{c}\text { Annualized Net } \\
\text { Present Value } \\
\text { (US } \$ \text { ) }\end{array}$ & $\begin{array}{c}\text { Discounted } \\
\text { Payback Periods }\end{array}$ \\
\hline Scenario 1 & $\$ 105,225.34$ & $\$ 9,517.86$ & 19.49 years \\
\hline Scenario 2 & $\$ 2,511,359.12$ & $\$ 162,177.55$ & 10.43 years \\
\hline Scenario 3 & $\$ 7,740,515.73$ & $\$ 499,864.53$ & 6.78 years \\
\hline Scenario 4 & $-\$ 1,188,251.10$ & $-\$ 76,734.83$ & n.a. \\
\hline Scenario 5 & $\$ 1,217,882.67$ & $\$ 78,647.79$ & 17.33 years \\
\hline Scenario 6 & $\$ 6,447,039.28$ & $\$ 416,334.78$ & 10.60 years \\
\hline
\end{tabular}

Note: 1 "n.a." indicates the project could not payback before the end of its economic life.

${ }^{2}$ Details of relative price scenarios are:

Scenario 1: HFO price - mild growth; LNG price - downward trend;

Scenario 2: HFO price - mild growth; LNG price - upward trend

Scenario 3: HFO price - mild growth; LNG price - stable

Scenario 4: HFO price - rapid growth; LNG price - downward trend

Scenario 5: HFO price - rapid growth; LNG price - upward trend

Scenario 6: HFO price - rapid growth; LNG price - stable

If the price differentials were in the opposite sign that prices of LNG are actually higher than that of HFO, as under the earlier years in Scenario 4, there would be no fuel cost saving to compensate the large original capital expenditure. Even though the sign of price difference has turned around and expands very fast in the later years under Scenario 4, the investment could not payback before end of its economic life, and NPV and ANPV are both negative.

Similarly, Table 4 presents the economic evaluation result for Ferry B under the six relative fuel price scenarios. In three out of the six scenarios, converting Ferry B to run on LNG would generate positive NPV and ANPV, and the project will payback within the economic life of the new system. Again, the investment would achieve payback fastest if the price scenario is as under scenario 3. Discounted payback period under such scenario is only 8.56 years, longer than for Feeder A, and NPV is US $\$ 4,155,638.26$, which is equivalent to annual after-tax net benefits of US $\$ 268,361.34$.

Table 4: Economic Evaluation of Retrofitting Ferry B.

\begin{tabular}{|c|c|c|c|}
\hline $\begin{array}{c}\text { Relative Fuel- } \\
\text { Price Scenarios }\end{array}$ & $\begin{array}{c}\text { Net Present Value } \\
\text { (NPV) } \\
(\text { US } \$ \text { ) }\end{array}$ & $\begin{array}{c}\text { Equivalent } \\
\text { Annualized Value } \\
\text { (US\$) }\end{array}$ & $\begin{array}{c}\text { Discounted Payback } \\
\text { Periods }^{1}\end{array}$ \\
\hline Scenario 1 & $-\$ 793,392.02$ & $-\$ 71,764.05$ & n.a. \\
\hline Scenario 2 & $\$ 766,211.91$ & $\$ 49,479.93$ & 14.161 years \\
\hline Scenario 3 & $\$ 4,155,638.26$ & $\$ 268,361.34$ & 8.56 years \\
\hline Scenario 4 & $-\$ 1,631,795.51$ & $-\$ 105,377.91$ & n.a. \\
\hline Scenario 5 & $-\$ 72,191.58$ & $-\$ 4,662.25$ & n.a. \\
\hline Scenario 6 & $\$ 3,317,234.77$ & $\$ 214,219.16$ & 12.66 years \\
\hline
\end{tabular}

Note: "1 "a." indicates the project could not payback before the end of its economic life.

${ }^{2}$ Refer to Table 3 for details of relative price scenarios.

On the other hand, if relative price scenarios are as under Scenario 1, 4, and 5, the fuel cost savings and tax savings generated throughout the economic life are not adequate to compensate the large original capital expenditure, and NPV's and ANPV's are all negative. Such a result indicates that the economic feasibility of running on LNG varies according to the ship types, and how the ships operate. Both of our case ships are not very different in size and power rating, and both run on 
regular schedule. Ferry B, however, being a passenger and cargo ships, may have to stress on the passenger comfort and have more no service days due to weather or sea condition. As a result, it takes longer for Ferry B to generate the needed monetary benefits to recover the original investment.

Figure 1 depicts how the original capital investment was gradually recovered by the present value of the after-tax net cash flows under each the six relative-price scenarios for both ships. It also displays the ranking of the payback period and NPV for the six scenarios. The patterns are very similar for both Feeder A and Ferry B, except that discounted payback periods are all deferred for Ferry B under every scenario. Generally, fuel price differentials determine how fast the initial investment is recovered. As Figure 1 shows, the fastest recovery is expected when price differential is as assumed in Scenario 3 , while the slowest recovery (or no recovery) is expected if as Scenario 4. One point worth noting is that the ranking under payback period is not necessarily the same as for NPV. For example, under Scenario 6, the project would generate the second highest NPV at the end of the economic life, but its payback period would only rank the third shortest.

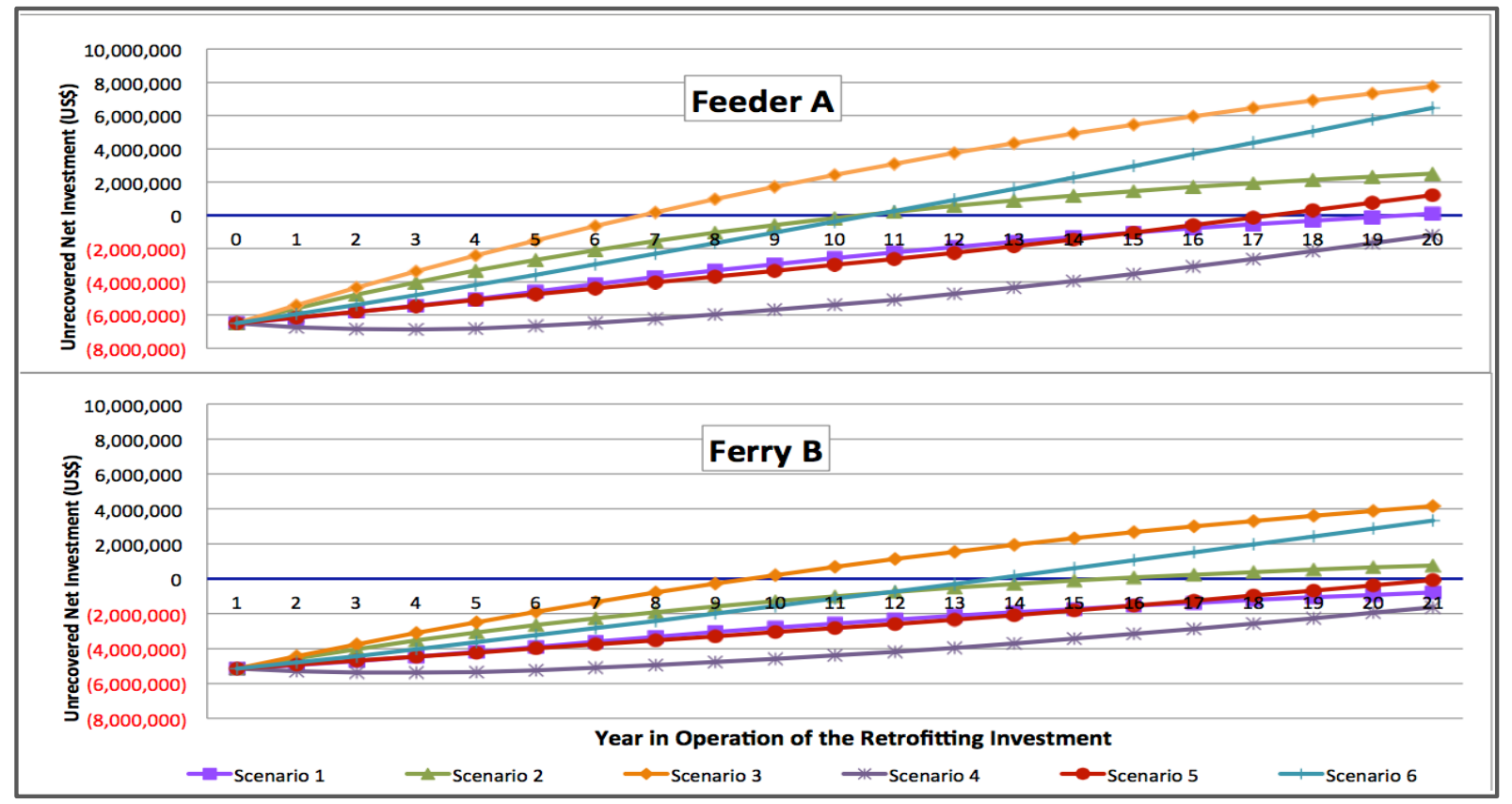

Fig. 1: The Unrecovered Net Investment for Both Ships under Various Future Fuel Price Scenarios.

Note: Refer to Table 3 for details of relative price scenarios.

\subsection{Cost Effectiveness}

Figure 2 present the MAC for using LNG as marine fuel in terms of GHG emission reduction. After considering six scenarios of the price differentials, as well as three scenarios of fuel supply chains, we found MACs are mostly with negative value, indicating the abatement strategy results in marginal benefits instead. For example, we found average MAC for Feeder $\mathrm{A}$ is -0.043 per $\mathrm{kg}-\mathrm{CO}_{2} \mathrm{e}$. Furthermore, the MAC varied between the two ships. Generally, Ferry B has higher MAC than that of Feeder A, either in counting all GHG emissions from full fuel life cycle or considering only the emissions from operation stage. 


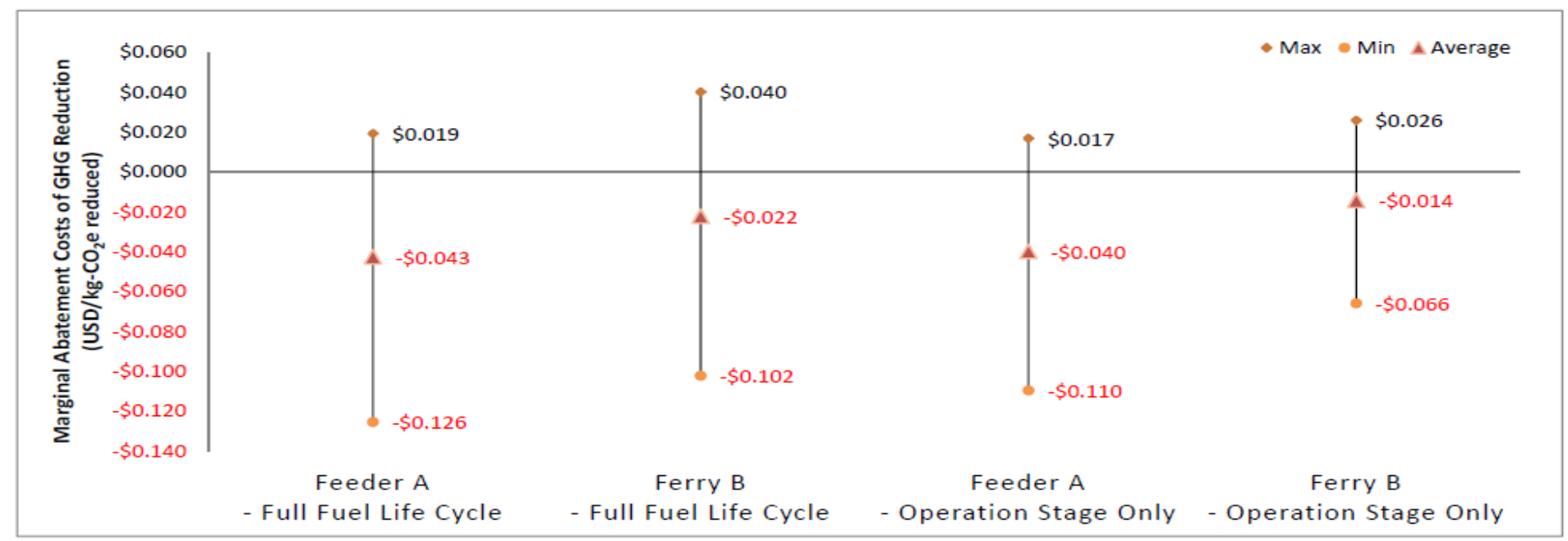

Fig. 2: Marginal Abatement Costs for GHG Emission Reduction through Alternative Fuel, LNG.

Note: Negative costs indicate marginal benefits were resulted from emission reduction.

Marginal abatement cost ranges from -0.126 to 0.040 USD per kg-CO2e when considering GHG reduction alone, indicating minimal economic benefit realizable from the application. As a result, we suspected the strategy would attract as much interest from the marine shipping companies operating around Taiwan Strait.

\section{Conclusion}

Our results indicated that the technology is more economically feasible if the price difference of HFO above LNG is large enough, and is generally more feasible for the Feeder than the ferry. For the feeder, on most scenarios (5 of 6), the technology investment can be recovered within 20 years and has positive net present value; the shortest present value payback period is 6.78 years. For the ferry, on only half of the scenarios ( 3 of 6 ), the technology investment can be recovered within 20 years and has positive net present value; the present value payback period for the recoverable scenarios ranges from 8.56 to 14.61 years. Our findings seem to confirm that the switch to LNG as ship fuel, though can greatly improve air quality, can be minimally economic beneficial to the marine shipping companies operating in Taiwan Strait. Without an ECA designation for the water area around Taiwan Strait or any incentives from the government, shipping companies are not likely to voluntarily introducing the application.

\section{References}

[1] IMO, "Sulphur Limits in Emission Control Areas From 1 January 2015," 2016. [Online]. Available: http://www.imo.org/en/MediaCentre/HotTopics/GHG/Documents/sulphur limits FAQ.pdf, [23 June, 2016].

[2] USEPA, "Regulatory Announcement - Designation of North American Emission Control Area to Reduce Emissions from Ships," March 2010. [Online]. Available: https://www.epa.gov/nscep [May 23, 2018]

[3] K. Capaldo, J. J. Corbett, P. Kasibhatla, P. Fischbeck, and S. N. Pandis, "Effects of ship emissions on sulphur cycling and radiative climate forcing over the ocean," Nature, vol. 400, p. 743, 08/19/online 1999.

[4] J. J. Corbett, P. S. Fischbeck, and S. N. Pandis, "Global nitrogen and sulfur inventories for oceangoing ships," Journal of Geophysical Research: Atmospheres, vol. 104, no. D3, pp. 3457-3470, 1999.

[5] E. Øyvind et al., "Emission from international sea transportation and environmental impact," Journal of Geophysical Research: Atmospheres, vol. 108, no. D17, 2003.

[6] Ø. Endresen, J. Bakke, E. Sørgård, T. Flatlandsmo Berglen, and P. Holmvang, "Improved modelling of ship SO2 emissions - a fuel-based approach," Atmospheric Environment, vol. 39, no. 20, pp. 3621-3628, 2005.

[7] V. Eyring et al., "Transport impacts on atmosphere and climate: Shipping," Atmospheric Environment, vol. 44, no. 37, pp. 4735-4771, 2010.

[8] IMO, "Resolution MEPC.203(62) - Amendments to the Annex of the Protocol of 1997 to amend the International Convention for the Prevention of Pollution from Ships, 1973, as Modified by the Protocol of 1978 Relating Thereto 
(MARPOL)," 2013. [Online]. Available: http://asp.mot.gov.il/en/shipping/imo-resolutions/mepc/815-mepc203-62, [23 May, 2018]

[9] IMO, "Third IMO GHG Study 2014," IMO2014. [Online]. Available: http://www.imo.org/en/OurWork/Environment/PollutionPrevention/AirPollution/Pages/Greenhouse-Gas-Studies2014.aspx

[10] A. Järvi, "Methane slip reduction in Wärtsilä lean burn gas engines," in 26th CIMAC World Congress on Combustion Engines, 2010.

[11] J. Nielsen and D. Stenersen, "Emission factors for CH4, NOX, particulates and black carbon for domestic shipping in Norway, revision 1," in "Klima og forurensningsdirektoratet: Marintek," 2010. [Online]. Available: http://www.miljodirektoratet.no/old/klif/publikasjoner/2746/ta2746.pdf [21 February 2015]

[12] R. A. Alvarez, S. W. Pacala, J. J. Winebrake, W. L. Chameides, and S. P. Hamburg, "Greater focus needed on methane leakage from natural gas infrastructure," Proceedings of the National Academy of Sciences, vol. 109, no. 17, pp. 64356440, 2012.

[13] M. Anderson, K. Salo, and E. Fridell, "Particle- and Gaseous Emissions from an LNG Powered Ship," Environmental Science \& Technology, vol. 49, no. 20, pp. 12568-12575, 2015.

[14] H. Thomson, J. J. Corbett, and J. J. Winebrake, "Natural gas as a marine fuel," Energy Policy, vol. 87, pp. 153-167, 2015.

[15] J. Hua, Y. Wu, and $\mathrm{H}$. Chen, "Alternative fuel for sustainable shipping across the Taiwan Strait," Transportation Research Part D: Transport and Environment, vol. 52, pp. 254-276, 2017.

[16] R. Verbeek et al., "Environmental and Economic aspects of using LNG as a fuel for shipping in The Netherlands," TNO (www.tno.nl), Netherlands, TNO report TNO-RPT-2011-00166. March 2011.

[17] A. Linde Cryo, "LNG ship to ship bunkering procedure," in Uddevalla: Swedish Marine Technology Forum, 2010.

[18] S. Åström, K. Yaramenka, H. Winnes, E. Fridell, and M. Holland, "The costs and benefits of a nitrogen emission control area in the Baltic and North Seas," Transportation Research Part D: Transport and Environment, vol. 59, pp. 223-236, 2018.

[19] A. Arteconi, C. Brandoni, D. Evangelista, and F. Polonara, "Life-cycle greenhouse gas analysis of LNG as a heavy vehicle fuel in Europe," Applied Energy, vol. 87, no. 6, pp. 2005-2013, 2010.

[20] S. K. Bengtsson, E. Fridell, and K. E. Andersson, "Fuels for short sea shipping: A comparative assessment with focus on environmental impact," Proceedings of the Institution of Mechanical Engineers, Part M: Journal of Engineering for the Maritime Environment, vol. 228, no. 1, pp. 44-54, 2013.

[21] P. C. Sames, N. B. Clausen, and M. L. Andersen, Costs and benefits of LNG as ship fuel for container vessels, 2011. [Online]. Available: https://marine.mandieselturbo.com/docs/librariesprovider6/technical-papers/costs-and-benefitsof-lng.pdf?sfvrsn=18

[22] M. Acciaro, "Real option analysis for environmental compliance: LNG and emission control areas," Transportation Research Part D: Transport and Environment, vol. 28, pp. 41-50, 2014.

[23] L. P. Blikom, "LNG - energy of the future, forecast marine fuel prices.," in DNVs LNG-blog vol. 2015, ed.: Det Norske Veritas (DNV).

[24] M. Saefong, "OPEC's latest prediction: \$160-a-barrel oil by 2035," in Energy Ticker: a Blog About How to Profit from the Ever-Changing Global Energy Market, ed: Market Watch,The Wall Street Journal Digital Network, 2013.

[25] A. A. Consulting, "Fuel cost projections.," 2012. [Online]. Available: http://www.acilallen.com.au/index [13 January, 2014]

[26] H. Rogers and J. Stern, "Challenges to JCC pricing ain Asian LNG markets," in "Oxford Institute for Energy Studies," OIES Paper, NG 81, 2014. [Online]. Available: https://ora.ox.ac.uk/objects/uuid:be050521-b368-491d-b13ba2e549917233 